\title{
CHARACTERIZATION AND PHENOTYPIC VARIABILITY IN NATURAL POPULATIONS OF MANGABEIRA IN THE STATE OF TOCANTINS, BRAZIL ${ }^{1}$
}

\author{
ELIZIA APARECIDA PINHEIRO ${ }^{2 *}$, RONALDO RODRIGUES COIMBRA ${ }^{3}$, KELLEN LAGARES FERREIRA SILVA $^{3}$, \\ WAGNER DE MELO FERREIRA ${ }^{3}$
}

\begin{abstract}
This study aimed to characterize three natural populations of mangabeira (Hancornia speciosa) located in parts of the Cerrado in the region of Porto Nacional, State of Tocantins, as well as to evaluate phenotypic variability in individual plants based on the physicochemical properties of their fruits. Ten genotypes were selected from each population, and 20 fruits of each genotype were collected for analysis. Fruits were analyzed for transverse and longitudinal diameters, total mass, pulp mass and yield, and number and fresh mass of seeds. Two seeds were taken from each fruit for the measurement of longitudinal and transverse diameter and thickness. Furthermore, $\mathrm{pH}$ and soluble solids were measured in the total pulp of each genotype. Descriptive statistics were performed on the data from morphological characterization, and populations were compared by the Kruskal-Wallis test, followed by Dunn's test at $5 \%$ probability level. The relationship between variables was estimated by the Spearman's correlation coefficient. Phenotypic variability was verified using the principal component analysis. All three natural populations of mangabeira investigated here exhibited similar characteristics regarding fruit morphology and $\mathrm{pH}$. Significant differences were detected only in the transverse diameter of the seed (Canaã had the highest value) and for total soluble solids content (Providência had the highest value). Significant correlations were found for corresponding morphological variables and $\mathrm{pH}$ in each population, except for several negative correlations that were observed in the Canaã population, which produced more homogeneous fruit. The Providência population presented the largest and most massive fruit. The greatest phenotypic variabilities were observed in the São Judas Tadeu and Providência populations.
\end{abstract}

Keywords: Apocynaceae. Cerrado. Hancornia speciosa. Morphology.

\section{CARACTERIZAÇÃO E VARIABILIDADE FENOTÍPICA DE POPULAÇÕES NATURAIS DE MANGABEIRA NO ESTADO DO TOCANTINS}

RESUMO - O presente estudo teve como objetivo caracterizar três populações naturais de mangabeira (Hancornia speciosa Gomes) localizadas em áreas de Cerrado na região de Porto Nacional-TO e estudar a variabilidade fenotípica através de atributos físico-químicos de frutos. Foram selecionados dez genótipos em cada população e coletados vinte frutos de cada genótipo para análise. Nos frutos foram mensurados: o diâmetro transversal e longitudinal, a massa total, a massa e o rendimento de polpa, o número de sementes e a massa fresca das sementes. De cada fruto foram retiradas duas sementes e mensurados o diâmetro longitudinal, transversal e espessura. Da polpa total de cada genótipo foram mensurados o $\mathrm{pH}$ e sólidos solúveis. Para caracterização morfológica foi realizada estatística descritiva, a comparação entre as populações foi realizada através do teste de Kruskal-Wallis seguido do teste de Dunn a 5\% de probabilidade. A relação entre as variáveis foi estimada pelo coeficiente de correlação de Spearman. Para o estudo da variabilidade fenotípica foi realizada a análise de componentes principais. As populações naturais de mangabeira estudadas apresentam características semelhantes quanto à morfologia do fruto e $\mathrm{pH}$, sendo encontrado diferenças significativas apenas para o diâmetro transversal da semente, com maior valor para Canaã e sólidos solúveis totais, com maior valor para Providência. As correlações significativas em cada população ocorrem para as mesmas variáveis morfológicas e $\mathrm{pH}$, com exceção das correlações negativas que ocorreram na população Canaã que se destacou por apresentar frutos mais homogêneos. Providência apresentou frutos maiores e com maior massa. Nas populações São Judas Tadeu e Providência foram observadas maiores variabilidades fenotípicas.

Palavras-chave: Apocynaceae. Cerrado. Hancornia speciosa. Morfologia.

\footnotetext{
${ }^{*}$ Corresponding author

${ }^{1}$ Received for publication in 10/30/2016; accepted in 07/06/2017.

Extracted from the Masters dissertation of the first author.

${ }^{2}$ Department of Biological Sciences, Escola Família Agrícola, Porto Nacional, TO, Brazil; eliziap@hotmail.com - ORCID: 0000-00015126-0986.

${ }^{3}$ Department of Genetic, Universidade Federal do Tocantins, Porto Nacional, TO, Brazil; ronaldo.rc@uft.edu.br - ORCID: 0000-00022888-7817, lagares@uft.edu.br - ORCID: 0000-0001-5010-8325, wmelo@uft.edu.br - ORCID: 0000-0002-7805-2180.
} 


\section{INTRODUCTION}

Mangabeira (Hancornia speciosa Gomes), belonging to the family Apocynaceae, occurs naturally in coastal tabuleiros, coastal lowlands, and the Cerrado of Brazil. It is a medium-sized tree with height varying from 4 to 7 meters (MONACHINO, 1945). Its fruits are berries that are ellipsoid or round in shape with a diameter ranging from 2.5 to $6.0 \mathrm{~cm}$; varying sizes and colors of fruits can occur in the same plant, where the fruit generally contains from 2 to 30 discoid seeds of 7 to $8 \mathrm{~mm}$ diameter (SILVA JÚNIOR; LÉDO, 2006; GANGA et al., 2010; SANTOS et al., 2012; NASCIMENTO; CARDOSO; COCOZZA, 2014). Ripe fruits of mangabeira usually have a characteristic aroma and flavor, and thus, are used for production of frozen pulps, juices, and ice creams. They are also appreciated for fresh consumption, besides being a food source for the wild fauna. Some parts of the plant are used to prepare folk medicine, and the latex extracted from its trunk is used in the production of rubber (SILVA JÚNIOR, 2004; SILVA; ARAÚJO; ROCHA, 2011; SANTOS et al., 2013).

Similar to many species of Apocynaceae, $H$. speciosa is an allogamous species. Although its flowers are hermaphrodite, there is an incompatibility between the reproductive structures that causes abortion of the fruits produced through self-pollination. The species, therefore, depends on cross fertilization, pollinating agents, and other plants of the same species for fruit production (ROWLEY, 1980; DIAS; MARANHÃO, 1994; DARRAULT; SCHLINDWEIN, 2006). Mangabeira seeds are recalcitrant and lose their germinative potential with dehydration (CARVALHO; MÜLLER; NASCIMENTO, 1999). Being a plant of seasonal behavior in the Cerrado, its pollinators require a matrix of natural vegetation with high diversity and heterogeneity of plant species that can provide food in periods when $H$. speciosa is not flowering (DARRAULT; SCHLINDWEIN, 2006). The flowering and fruiting periods of mangabeira species vary according to the region of occurrence and may produce one or two annual crops (SILVA JÚNIOR; LÉDO, 2006).

Studies on $H$. speciosa are recent and limited in number, especially on plants of this species from the Cerrado region in Brazil. Because it is an allogeneic species, it has great genetic diversity; the maintenance of this diversity within the populations is what allows the continuity of its evolutionary process (FERREIRA; MORETZSOHN; BUSO, 2007). It is, therefore, essential to develop programs to conserve mangabeira's genetic resources by maintaining the species in its natural environment (in situ). The knowledge of its genetic resources will be made available by studies that characterize the genetic variability of natural populations, and thus allow establishment of the best way to conserve these resources (HOSBINO et al., 2002; MOURA et al., 2005) in H. speciosa, which has suffered from much genetic erosion due to the loss or alteration of its natural habitat (GANGA et al., 2010; SILVA; ARAÚJO; ROCHA, 2011; SÁ; LÉDO; LÉDO, 2011).

Many studies on the variability of natural populations of $H$. speciosa are conducted on its fruit because there are significant variations between fruits of different plants of the same population. Fruits of mangabeira are also a good choice for this study owing to their increasing commercial value, and the fact that mangabeira's propagation occurs through seeds carried by the fruit.

Therefore, the study of the phenotypic variability in natural populations of this species is important, as it provides the knowledgebase that can aid in its management and conservation, thus maintaining its diversity in plant ecosystems. Genotypes can also be identified for the formation of germplasm banks that may facilitate the establishment of breeding programs of the species. In case of the Cerrado region, investigations of this nature are highly relevant, considering its high plant diversity and its current state of degradation. Such studies highlight alternative species, such as mangabeira, that can be planted for restoration of the natural vegetation in this and other degraded regions (SILVA et al., 2013; RIBEIRO et al., 2015; FERRO et al., 2016). In this context, this study aims to characterize and analyze the phenotypic variability of natural populations of $H$. speciosa based on variables in its fresh fruit.

\section{MATERIAL AND METHODS}

The work was carried out with three natural populations of $H$. speciosa, var. speciosa, occurring in a typical Cerrado area; they were sampled from inside private properties located in the municipality of Porto Nacional, State of Tocantins, Brazil. The population of São Judas Tadeu is located on the margins of the TO 070 highway, which connects Porto Nacional to Brejinho de Nazaré, $24 \mathrm{~km}$ from Porto Nacional $\left(10^{\circ} 48^{\prime} 0.6^{\prime \prime} \mathrm{S}\right.$ and $48^{\circ} 25^{\prime} 37.3^{\prime \prime} \mathrm{W}$, $260 \mathrm{~m}$ altitude). The Canaã population is located on the margins of the TO 230 highway, approximately $10 \mathrm{~km}$ from the urban area of Porto Nacional toward Monte do Carmo $\left(10^{\circ} 40^{\prime} 23.1^{\prime \prime} \mathrm{S}\right.$ and $48^{\circ} 20^{\prime} 54.3^{\prime \prime} \mathrm{W}$, $280 \mathrm{~m}$ altitude), and the Providência population is located on the margins of the TO 050 highway that connects Porto Nacional to Palmas, $18 \mathrm{~km}$ from Porto Nacional $\left(10^{\circ} 33^{\prime} 31.2^{\prime \prime} \mathrm{S}\right.$ and $48^{\circ} 24^{\prime} 43.8^{\prime \prime} \mathrm{W}$, $220 \mathrm{~m}$ altitude).

Porto Nacional is 212 meters above sea level and the climate is characterized by two seasons: a dry season (May to September) and a rainy season (October to April). This is climate Aw according to the Köppen classification. The mean annual 
temperature is $26.1^{\circ} \mathrm{C}$, and the mean annual rainfall is around $1667.9 \mathrm{~mm}$ (SOUZA; GOMES, 2012).

The genotypes of each population were georeferenced with a Global Positioning System (GPS) receiver and numbered with aluminum plates, in order to facilitate locating and identifying them in the field. Ten adult genotypes from each population were sampled in October 2013 with 20 fruits collected per genotype. These adult plants had their fruits at the stage of physiological maturity and were located at least 20 meters apart from one another. Determination of the sampled genotypes was performed in accordance with preliminary studies done previously by Freitas et al. (2012); Santos (2013); and Matos (2013). They were considered representatives of the phenotypic variability of each population.

Ten soil samples were also collected from a depth of 0 to $20 \mathrm{~cm}$ to characterize soil conditions in each study area. Soil samples were classified according to the simplified soil texture triangle classification of Embrapa and compared using the fifth approximation for the State of Goiás.

The 20 fruits sampled from each genotype were measured for their longitudinal (LDF, mm) and transverse diameter (TDF, $\mathrm{mm}$ ) using a digital caliper. Mass of the fruit (FM, g), fresh seed mass (DM, g), and pulp mass (PM, g) were obtained through an analytical scale. The number of seeds (NS, un.) was counted manually. Pulp yield (PY, \%), was calculated using the following equation: $\mathrm{PY}=\frac{(\mathrm{PMI} \times 100)}{\text { FMI }}$

from each genotyp diamerer analyzed for transverse (TDS, mm), longitudinal diameter (LDS, mm), and thickness ( $\mathrm{T}, \mathrm{mm}$ ) using a digital caliper.

Pulp of fruits from the same genotype were grouped, and later, a direct reading of the soluble solids content in ${ }^{\circ}$ Brix was obtained at a temperature of $20^{\circ} \mathrm{C}$ using a portable refractometer with a measurement range of 0.0 to $53.0 \%$.

The potential of hydrogen $(\mathrm{pH})$ of the pulp was measured by placing the electrode directly on the pulp using a glass membrane potentiometer, adjusted with buffers of $\mathrm{pH} 7$ and 4 .

In order to characterize the morphology of the populations, descriptive statistics were performed on the data obtained, and the relationship between the variables studied was estimated by the Spearman correlation coefficient. It was hypothesized that the correlation coefficient is zero and this was tested by $t$ statistics at $5 \%$ probability. Populations were compared by the Kruskal-Wallis test, followed by Dunn's test at $5 \%$ probability. For the study of phenotypic variability, principal component analysis (PCA) was applied, where the first three main components were used to make a three-dimensional graph. All analyses were run using Statistica 7.0 software.

\section{RESULTS AND DISCUSSION}

Soil analyses revealed that the soil in which the Canaã population grew had a higher percentage of clay and silt, and consequently, a lower percentage of sand; it was thus, classified as sandy clay, while the other soils were classified as sandy loams. According to the fifth approach for the State of Goiás, the soils in which the populations of São Judas and Providência grew were strongly acidic, i.e., had very low $\mathrm{pH}$, along with low levels of calcium and magnesium. Medium levels of these parameters were present in the soil around Canaã population. Phosphorus content was found to be low in all areas. Potassium content was medium in the soils around São Judas Tadeu and Providência populations and high in the soil around Canaã population. In general, it was noted that all soil samples were poor in nutrients and overall quality with low organic matter content and high acidity and aluminum content. Nevertheless, the soil around the Canaã population was slightly more fertile with higher contents of zinc and copper as well as higher cation exchange capacity (CEC) (Table 1).

The mean temperature during the study period increased through July, August, and September, with a slight reduction in October, coinciding with the higher rainfall $(103.4 \mathrm{~mm})$ of that season. In July, there was no rainfall, while there was little rainfall in August $(11.0 \mathrm{~mm})$ and September $(8.4 \mathrm{~mm})$. The highest maximum temperature in these months was $38.0^{\circ} \mathrm{C}$ in September, and the lowest minimum was $20.8^{\circ} \mathrm{C}$ in August (Figure 1).

The populations showed similarities in the variables investigated here for their fruits and seeds as well as in the chemical characteristics of their fruit pulp; Exceptions to this were the transverse diameter of the seed $(p=0.0167)$ and total soluble solids $(p=0.0002)$. The differences between genotypes of the same population were mainly attributable to the large variations in fruit mass (FM), seed mass (SM), pulp mass (PM), and number of seeds (NS) (Table 2). This large variability in the morphology of seeds and fruits within the populations was also reported by Freitas et al. (2012) in a morphological characterization study on the Canaã population in 2009. 
Table 1. Physical and chemical properties of the soils around the sampled populations of São Judas Tadeu, Canaã, and Providência, Porto Nacional, State of Tocantins.

\begin{tabular}{|c|c|c|c|}
\hline \multirow{2}{*}{ Components } & \multicolumn{3}{|c|}{ Populations } \\
\hline & São Judas Tadeu & Canaã & Providência \\
\hline \multicolumn{4}{|l|}{ Particle Size Analysis } \\
\hline Clay (\%) & 16.70 & 32.00 & 16.80 \\
\hline Silt (\%) & 10.80 & 16.00 & 11.10 \\
\hline Sand (\%) & 72.50 & 52.00 & 72.10 \\
\hline \multicolumn{4}{|l|}{ Chemical Analysis } \\
\hline $\mathrm{pH} \mathrm{CaCl} 2$ & 4.14 & 3.94 & 4.14 \\
\hline $\mathrm{Ca}(\mathrm{meq} / 100 \mathrm{~mL})$ & 0.23 & 0.18 & 0.17 \\
\hline $\mathrm{Mg}(\mathrm{meq} / 100 \mathrm{~mL})$ & 0.15 & 0.14 & 0.13 \\
\hline $\mathrm{Al}(\mathrm{meq} / 100 \mathrm{~mL})$ & 0.54 & 1.05 & 0.43 \\
\hline $\mathrm{H}+\mathrm{Al}(\mathrm{meq} / 100 \mathrm{~mL})$ & 4.40 & 12.21 & 3.67 \\
\hline $\mathrm{K}(\mathrm{meq} / 100 \mathrm{~mL})$ & 0.10 & 0.15 & 0.08 \\
\hline $\mathrm{P}\left(\mathrm{mg} / \mathrm{dm}^{3}\right)$ & 2.69 & 2.49 & 2.16 \\
\hline $\mathrm{S}\left(\mathrm{mg} / \mathrm{dm}^{3}\right)$ & 1.99 & 1.78 & 1.99 \\
\hline OM. $(\%)$ & 0.65 & 2.13 & 0.24 \\
\hline $\mathrm{Zn}\left(\mathrm{mg} / \mathrm{dm}^{3}\right)$ & 0.12 & 0.39 & 0.12 \\
\hline $\mathrm{Cu}\left(\mathrm{mg} / \mathrm{dm}^{3}\right)$ & 0.36 & 0.59 & 0.38 \\
\hline $\mathrm{Fe}\left(\mathrm{mg} / \mathrm{dm}^{3}\right)$ & 80.60 & 46.70 & 72.10 \\
\hline $\operatorname{Mn}\left(\mathrm{mg} / \mathrm{dm}^{3}\right)$ & 32.40 & 3.70 & 2.20 \\
\hline CEC & 4.87 & 12.68 & 4.06 \\
\hline V $(\%)$ & 9.76 & 3.75 & 9.44 \\
\hline
\end{tabular}

Content of: $\mathrm{pH} \mathrm{CaCl}_{2}=\mathrm{pH}$ in calcium chloride; $\mathrm{Ca}=$ calcium; $\mathrm{Mg}=$ magnesium; $\mathrm{Al}=$ aluminum; $\mathrm{H}+\mathrm{Al}=$ hydrogen + aluminum; $\mathrm{K}=$ potassium; $\mathrm{P}=$ phosphorus; $\mathrm{S}=$ sulfur; $\mathrm{OM}$. = organic matter; $\mathrm{Zn}=$ zinc; $\mathrm{Cu}=$ copper; $\mathrm{Fe}=$ iron; $\mathrm{Mn}=$ manganese; $\mathrm{CEC}=$ cation exchange capacity; $\mathrm{V}=$ base saturation

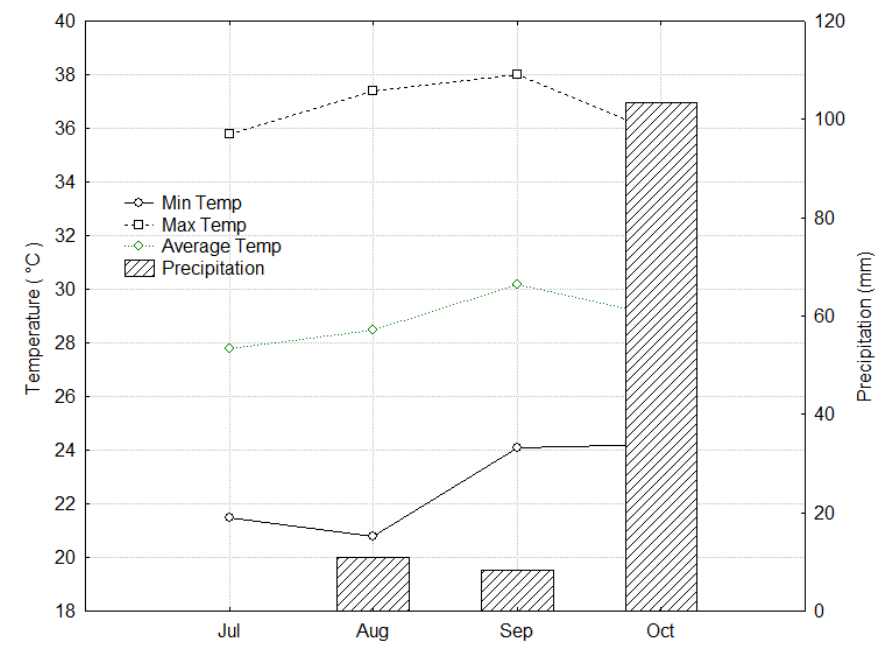

Figure 1. Temperature and rainfall in the months before fruit collection and in the months of collection in Porto Nacional, State of Tocantins. 
Table 2. Descriptive statistics and comparison of the populations of São Judas Tadeu, Canaã, and Providência, considering the variables studied for fruits and seeds as well as chemical characteristics of the pulp. Values were obtained from fruits collected in October 2013 from Porto Nacional, State of Tocantins.

\begin{tabular}{|c|c|c|c|c|c|c|c|c|c|c|c|c|}
\hline $\begin{array}{l}\text { São Judas } \\
\text { Tadeu }\end{array}$ & $\begin{array}{l}\text { LDF } \\
(\mathrm{mm}) \\
\end{array}$ & $\begin{array}{l}\text { TDF } \\
(\mathrm{mm}) \\
\end{array}$ & $\begin{array}{r}\text { FM } \\
(\mathrm{g}) \\
\end{array}$ & $\begin{array}{l}\text { SM } \\
(\mathrm{g}) \\
\end{array}$ & $\begin{array}{r}\text { PM } \\
\text { (g) } \\
\end{array}$ & $\begin{array}{l}\text { NS } \\
\text { (un.) } \\
\end{array}$ & $\begin{array}{l}\text { TDS } \\
(\mathrm{mm}) \\
\end{array}$ & $\begin{array}{l}\text { LDS } \\
(\mathrm{mm}) \\
\end{array}$ & $\begin{array}{c}\mathrm{T} \\
(\mathbf{m m}) \\
\end{array}$ & $\begin{array}{l}\text { PY } \\
(\%) \\
\end{array}$ & ${ }^{\circ}$ BRIX & pH \\
\hline Minimum & 27.53 & 28.21 & 15.30 & 1.47 & 12.55 & 5.00 & 7.38 & 9.86 & 2.70 & 75.60 & 15.50 & 3.07 \\
\hline Maximum & 42.25 & 41.03 & 45.49 & 7.15 & 36.73 & 17.60 & 9.40 & 12.04 & 3.42 & 88.16 & 19.00 & 3.77 \\
\hline Mean & $35.98 \mathrm{a}$ & $35.37 \mathrm{a}$ & $30.48 \mathrm{a}$ & $3.91 \mathrm{a}$ & $24.83 \mathrm{a}$ & $10.87 \mathrm{a}$ & $8.43 b$ & $10.69 \mathrm{a}$ & $3.11 \mathrm{a}$ & $82.30 \mathrm{a}$ & $17.17 \mathrm{a}$ & $3.34 \mathrm{a}$ \\
\hline CV (\%) & 12.06 & 11.50 & 31.03 & 50.47 & 29.73 & 42.24 & 6.13 & 5.94 & 8.30 & 4.78 & 8.03 & 6.00 \\
\hline \multicolumn{13}{|l|}{ Canaã } \\
\hline Minimum & 32.30 & 24.98 & 11.54 & 2.20 & 8.78 & 6.20 & 8.46 & 10.39 & 2.85 & 67.30 & 11.00 & 3.15 \\
\hline Maximum & 39.84 & 37.30 & 33.03 & 8.21 & 26.85 & 19.20 & 9.61 & 12.78 & 3.53 & 87.58 & 16.00 & 3.76 \\
\hline Mean & $35.23 \mathrm{a}$ & $33.90 \mathrm{a}$ & $25.48 \mathrm{a}$ & $5.05 \mathrm{a}$ & $19.27 \mathrm{a}$ & $13.61 \mathrm{a}$ & $8.99 \mathrm{a}$ & $11.40 \mathrm{a}$ & $3.29 \mathrm{a}$ & $75.70 \mathrm{a}$ & $13.90 \mathrm{~b}$ & $3.53 \mathrm{a}$ \\
\hline CV (\%) & 6.15 & 10.29 & 24.32 & 38.67 & 28.50 & 37.53 & 4.74 & 6.18 & 6.88 & 8.87 & 12.32 & 6.11 \\
\hline \multicolumn{13}{|l|}{ Providência } \\
\hline Minimum & 29.47 & 29.91 & 17.72 & 2.90 & 14.03 & 8.30 & 7.86 & 10.21 & 2.64 & 64.53 & 15.00 & 3.31 \\
\hline Maximum & 44.53 & 43.51 & 52.38 & 10.94 & 37.98 & 32.30 & 9.67 & 12.51 & 3.71 & 85.25 & 19.00 & 3.70 \\
\hline Mean & $38.49 \mathrm{a}$ & $36.97 \mathrm{a}$ & $33.77 \mathrm{a}$ & $5.27 \mathrm{a}$ & $26.19 \mathrm{a}$ & $14.97 \mathrm{a}$ & $8.48 b$ & $11.17 \mathrm{a}$ & $3.17 \mathrm{a}$ & $78.81 \mathrm{a}$ & $17.38 \mathrm{a}$ & $3.43 \mathrm{a}$ \\
\hline $\begin{array}{l}\text { CV (\%) } \\
\text { Overall }\end{array}$ & 13.96 & 13.29 & 34.14 & 50.26 & 31.55 & 52.44 & 6.35 & 6.53 & 10.94 & 9.65 & 6.36 & 3.44 \\
\hline Mean & 36.57 & 35.41 & 29.91 & 4.74 & 23.43 & 13.15 & 8.63 & 11.09 & 3.19 & 78.93 & 16.15 & 3.44 \\
\hline
\end{tabular}

Values followed by different letters in the same column are significantly different as analyzed through the Kruskal-Wallis test, followed by Dunn's test at 5\% probability.

$\mathrm{LDF}=$ longitudinal diameter of the fruit; $\mathrm{TDF}=$ transverse diameter of the fruit; $\mathrm{FM}=$ mass of the fruit; $\mathrm{SM}=$ mass of the seed; PM = mass of the pulp; NS = number of seeds; TDS = transverse diameter of the seed; LDS $=$ longitudinal diameter of the seed; $\mathrm{T}=$ thickness of the seed; PY $=$ pulp yield; ${ }^{\circ}$ BRIX $=$ soluble solids of the pulp; $\mathrm{pH}=$ potential of hydrogen of the pulp.

Fruit size is an important variable, considering that $H$. speciosa has value as food source and is used by local communities and industries (SANTOS et al., 2013; GONÇALVES et al., 2013). According to the results obtained here, there are variations possible in $H$. speciosa fruit size between and within populations. The mean values for dimensional variables of the fruit were $36.57 \mathrm{~mm}$ for longitudinal diameter and $35.41 \mathrm{~mm}$ for transverse diameter. These results are similar to those found by Ganga et al. (2010) in a study on physical characterization of fruits of mangabeira populations in the Cerrado, in the states of Goiás, Tocantins, Mato Grosso, Mato Grosso do Sul, and Bahia. They observed mean values of $37.3 \mathrm{~mm}$ for longitudinal diameter and $34.0 \mathrm{~mm}$ for transverse diameter. Results deviated from the overall mean presented herein, but within their range of variation, these results are corroborated by previous research by Capinan et al. (2007), who characterized fruits from plants in the State of Bahia, to report a mean value of $35.47 \mathrm{~mm}$ for longitudinal diameter and $30.70 \mathrm{~mm}$ for transverse diameter.

The overall mean value for fruit mass was $29.91 \mathrm{~g}$ and $23.43 \mathrm{~g}$ for pulp mass, which was higher than those reported by Nascimento, Cardoso and Cocozza (2014), who found mean values of $17.17 \mathrm{~g}$ for fruit mass and $14.77 \mathrm{~g}$ for pulp mass, and by Freitas et al. (2012), who found mean values of
$20.97 \mathrm{~g}$ for fruit mass and $10.30 \mathrm{~g}$ for pulp mass. Our values were, however, similar to those reported by Ganga et al. (2010), who recorded mean values of $27.88 \mathrm{~g}$ for fruit mass and 23.61 for pulp mass. Gonçalves et al. (2013) found higher mean values of $46.49 \mathrm{~g}$ for fruit mass and $40.15 \mathrm{~g}$ for pulp mass in a study on mangabeira characterization in Cerrado's natural vegetation located in the eastern region of the State of Mato Grosso.

Considering the pulp yield of the three populations, the overall mean value was $78.93 \%$, while the actual yields ranged from 75.7 (Canaã) to $82.3 \%$ (São Judas Tadeu) - a result higher than that found by Freitas et al. (2012), who reported mean value of $49.73 \%$, and lower than the yields observed by Ganga et al. (2010), who reported it to be $82.68 \%$; Capinan et al. (2007), who reported yield to be 83.94\%; and Nascimento, Cardoso and Cocozza (2014), who reported pulp yield of $85.93 \%$. These variations in pulp yield are possibly due to the soil and climatic conditions in the region and genetic variability of the plants.

As per the dimensional characteristics of the fruit: i.e., LDF (mm) and TDF (mm), fruit mass (FM $(\mathrm{g})$, and pulp yield PY (\%), respectively, the following genotypes stood out: SJT5 $(41.3,39.8$, $41.5,77.2)$ and SJT9 $(42.3,41.0,45.5 ; 81.0)$ of the São Judas Tadeu population; C4 (39.8, 35.1, 32.2, $84.0)$ and $C 9(36.6,37.3,33.0,75.6)$ of the Canaã 
population; and P2 $(41.9,42.2,45.3,81.7)$ and P6 (44.5, 43.5, 52.4, 84.6) of the Providência population. As these genotypes presented the highest values for these characteristics, they are proposed to be the most promising candidates for the formation of germplasm banks.

Regarding the seeds, the Canaã population had higher TDS $(8.99 \mathrm{~mm})$ as compared to the São Judas Tadeu $(8.43 \mathrm{~mm})$ and Providência $(8.48 \mathrm{~mm})$ populations. As far as the number of seeds per fruit was concerned, the overall mean was 13.15 seeds, ranging from 5.00 to 32.30 seeds per fruit with a mean seed mass of $4.74 \mathrm{~g}$ and mass range of 1.47 to $10.94 \mathrm{~g}$. These values were higher than those reported by Capinan et al. (2007), i.e., mean values of 10.3 seeds per fruit and $2.52 \mathrm{~g}$ for seed mass, but were similar to those found by Ganga et al. (2010) for the mean number of seeds (13.4 per fruit) and higher for the mean seed mass $(3.88 \mathrm{~g})$. Freitas et al. (2012) obtained 16.10 for the mean number of seeds and $5.05 \mathrm{~g}$ for mean seed mass, while Gonçalves et al. (2013) found a mean value of 22 seeds per fruit and $6.33 \mathrm{~g}$ for the mean seed mass - all of which are higher than those found in this study.

Malavasi and Malavasi (2001) purported that seed size is related to the environment where the plant is established in favor of seedlings that can develop an extensive root system with the seed's own reserves. Hoffmann (2000) investigated Cerrado species and observed a positive correlation between seed size and seedling survival.

In our investigation, the studied populations of mangabeira showed no differences in their number of seeds, suggesting a similarity in their rates and frequencies of pollination. It is important to emphasize here that the presence of many seeds in $H$. speciosa fruits are indicative of a strong pollination process, which is a possibility for it, since the species is allogamous and depends on pollinating agents for fruit production (ROWLEY, 1980; DIAS; MARANHÃO, 1994). This is a factor that also highlights the diversity and heterogeneity of plant species in the Cerrado ecoregion that favors the presence of specific pollinators capable of providing food in periods, when $H$. speciosa is not flowering itself. The number of seeds is also important for the reproduction of the species, since the seeds of $H$. speciosa are recalcitrant and lose their germinative potential with dehydration (CARVALHO; MÜLLER; NASCIMENTO, 1999). Higher the number of seeds, the greater is the potential for reproduction. The presence of many pollinators is also important to avoid successive floral visits from the same pollinator to several flowers of the same plant, thus reducing the deposition of exogenous pollen and increasing the rate of transfer of geitonogamic pollen, which does not favor fruit production (DARRAULT; SCHLINDWEIN, 2006; PINTO; OLIVEIRA; SCHLINDWEIN, 2008; SCHLINDWEIN et al., 2012). Thus, the more pollinators there are, the higher is the fruiting rate, and consequently, larger fruits and more seeds are produced on the plant (GANGA et al., 2010).

In the case of seeds and pulp, the lower the number of seeds and the greater the amount of pulp, the more valuable the fruit will be for commercial purposes. Thus, the genotypes that showed the highest number of seeds: SJT7 (5.0) and STJ8 (6.9) from the São Judas Tadeu population, C3 (6.2) and C8 (7.4) from the Canaã population, and P7 (9.9) and P8 (10) from the Providência population, can be used for genetic improvement that aims to lower the number of seeds.

The soluble solids content expressed as ${ }^{\circ}$ Brix indicates the approximate amount of sugars present in the fruit (CHITARRA; CHITARRA; CARVALHO, 1981). It is related to the fruit flavor and can vary as per soil characteristics, climatic conditions, and genetic material (OLIVEIRA et al., 1999). Solids content is also influenced by the degree of maturation of the fruit (SILVA; MARTINS; DEUS, 2009). The species, H. speciosa, takes a period of approximately 110 days between flowering, filling, and maturation of the fruit (LORENZI, 1992; SILVA; NASCIMENTO; NAVES, 2006), while remaining exposed to the influence of several environmental factors during this period. The mean soluble solids content observed in the populations studied here was $16.15^{\circ}$ Brix. Lower content has been reported previously by Santos et al. (2012) and Carnelossi et al. (2004) with mean values of $14.83^{\circ}$ Brix and $15.2^{\circ}$ Brix in fresh fruit, respectively. Cohen and Sano (2010) found mean soluble solids values of $18.8^{\circ}$ Brix. Rufino (2008) reported a mean value of $21.5^{\circ}$ Brix, while Nascimento, Cardoso and Cocozza (2014) reported $17.04^{\circ}$ Brix, all of which are higher than the mean values observed herein. The content of soluble solids is directly related to the amount of water available at the time that the fruit is undergoing filling. Reduction in soluble solids may occur due to excess water, while high sugar concentration is favored by water deficit (SOUZA et al., 2010; SILVA; SILVA, 2012).

For the same variable, Canaã population presented a lower value of $13.90^{\circ}$ Brix as compared to the populations of São Judas Tadeu $\left(17.17^{\circ}\right.$ Brix $)$ and Providência $\left(17.38^{\circ}\right.$ Brix), although it grew on more fertile soil. This population shows a late ripening of the fruits as compared to the others, where the ripening process coincides with the onset of the rainy season. Possibly the excessive amount of water available to it is one of the factors favoring the least amount of soluble solids in this population. According to Pirani, Sanchez and Pedroni (2009), the reproductive phenology of plants in seasonal environments is shaped to synchronize the maturation of fruits and the release of seeds with the most favorable period for growth and development of the seedlings, which can be a strategy used by this 
population as well. The genotypes that stood out due to high soluble solids content ( ${ }^{\circ}$ Brix) were SJT9 (19.0) and SJT10 (19.0) from the population of São Judas Tadeu, C3 (15.0) and C8 (15.0) from the Canaã population, and P4 (18.0) and P5 (19.0) from the Providência population because of the highest values presented.

The degree of fruit maturation influences the $\mathrm{pH}$ because as the fruit ripens, its total acidity tends to decrease, and consequently, there is an increase in the $\mathrm{pH}$ and the soluble solids content (SILVA; MARTINS; DEUS, 2009). The mean $\mathrm{pH}$ of 3.44 found for the populations studied here is in agreement with the values quoted in previous works that reported $\mathrm{pH}$ to vary between 2.77 and 3.50 (FERREIRA et al., 2001; CARNELOSSI et al., 2004; RUFINO, 2008; COHEN; SANO, 2010; SANTOS et al., 2012). The pH is mainly influenced by genetic variability (PEYNAUD, 1997) and by the geographical location from where the fruits are harvested (SILVA; SILVA, 2012).

The variables, fruit mass, seed mass, pulp mass, and number of seeds, showed a large amplitude of variation within the populations, but these differences were similar to the findings of previous works by Capinan et al. (2007); Ganga et al. (2010); Gonçalves et al. (2013); Freitas et al. (2012); and Nascimento, Cardoso and Cocozza (2014). Furthermore, according to Ganga et al. (2010), the fruit mass is not a limiting factor for pulp yield.

The absolute values for these variables showed that Providência population actually had slightly higher mean values for most variables, such as fruit longitudinal diameter $(38.49 \mathrm{~mm})$, fruit transverse diameter $(36.97 \mathrm{~mm})$, fruit mass (33.77 g), seed mass (5.27 g), pulp mass (26.19 g), number of seeds (14.97 un.), and soluble solids content $\left(17.38^{\circ}\right.$ Brix) (Table 2$)$. Pulp yield is directly related to these fruit-related variables and has an inverse relationship with the number and mass of seeds. Thus, although the Providência population had larger fruit, it also presented many seeds, which contributed to a lower yield of pulp (78.81\%). On the contrary, in the population of São Judas Tadeu, large fruit with lower number of seeds contributed to a higher pulp yield (82.3\%). The Canaã population had smaller fruit and with many seeds, thus, also presented a lower yield of pulp (75.7\%). Importantly, the phenotypic characteristics responsible for this variability originate from several genetic and environmental factors. If there is a restriction to the gene flow, the effects of selection and drift can also promote genetic differentiation between populations (SILVA; CHAVES; NAVES, 2001; GANGA et al., 2010).

The large variability found within the populations studied here and also observed in other investigations on the same species, especially when comparing variables of fruits and seeds, can be partially explained by the need of cross fertilization and generation of fruits with very varied characteristics in the same plant. The environmental variations that occur each year, mainly in temperature and rainfall, probably influence the process of fruit formation, and thus lead to different responses that affect fruit characteristics. In agreement with Ferraz et al. (1999), besides the characteristics of each species, climatic variations influence phenology and also regulate the timing, intensity, duration, and periodicity of phenological events. Specifically, in the Cerrado, rainfall has been identified as a determinant of species phenology (FELFILI et al., 1999).

In this way, it can be explained why $H$. speciosa possesses great diversity within and between its populations, although it is threatened by the degradation of its natural habitats. This immense genetic diversity within the species and the factors, which affect it, need to be better known and exploited in order to allow the design of in situ conservation strategies as well as enhance the plant's commercial potential and genetic improvement.

To study the correlations between the variables of each population, the non-parametric Spearman correlation test was applied. This test was applied because the Canaã population did not show normality in the data on fruit transverse diameter (TDF; $p=0.01$ ) and the Providência population did not show normality in the seed mass data (SM; $\mathrm{p}=0.04)$, number of seeds (NS, $\mathrm{p}=0.0098)$, pulp yield (PY, $\mathrm{p}=0.0097)$, and $\mathrm{pH}(\mathrm{pH} ; \mathrm{p}=0.05)$, when analyzed by the Shapiro-Wilk test at $5 \%$ probability.

As compared to other populations, São Judas Tadeu had the highest number of significant and high magnitude correlations between the different variables studied (Table 3 ). In this population, the fruit size variables (TDF and LDF) had significant positive correlations with fruit mass (FM), seed mass (SM), pulp mass (PM), and number of seeds (NS), indicating that larger and heavier fruits also contain more seeds. This correlation depends directly on efficient pollination, which is reinforced by the significant correlation between pulp mass (PM) and number of seeds (NS).

The Canaã population had the lowest number of significant correlations and was the only population with significant negative correlations between the variables examined (Table 4). In this population, the fruit size variables (TDF and LDF) showed a significant positive correlation with fruit mass (FM) and pulp mass (PM). Seed mass (SM) also showed a positive correlation with the number of seeds (NS). For this population, a negative correlation between seed mass (SM) and pulp yield (PY) as well as between number of seeds (NS) and pulp yield (PY) reinforces an inverse relationship between the number and mass of the seeds with the pulp yield. 
Table 3. Correlation between variables of fruits, seeds, and chemical characteristics of the pulp of the São Judas Tadeu population. Values were obtained from fruits collected in October 2013 from Porto Nacional, State of Tocantins.

\begin{tabular}{|c|c|c|c|c|c|c|c|c|c|c|c|}
\hline $\begin{array}{l}\text { São Judas } \\
\text { Tadeu } \\
\end{array}$ & $\begin{array}{l}\text { LDF } \\
(\mathrm{mm}) \\
\end{array}$ & $\begin{array}{l}\text { TDF } \\
(\mathbf{m m}) \\
\end{array}$ & $\begin{array}{c}\text { FM } \\
(\mathrm{g}) \\
\end{array}$ & $\begin{array}{l}\text { SM } \\
(\mathrm{g}) \\
\end{array}$ & $\begin{array}{r}\text { PM } \\
(\mathrm{g}) \\
\end{array}$ & $\begin{array}{c}\text { NS } \\
\text { (und) } \\
\end{array}$ & $\begin{array}{r}\text { TDS } \\
(\mathbf{m m}) \\
\end{array}$ & $\begin{array}{l}\text { LDS } \\
(\mathrm{mm}) \\
\end{array}$ & $\begin{array}{c}T \\
(\mathbf{m m}) \\
\end{array}$ & $\begin{array}{l}\text { PY } \\
(\%) \\
\end{array}$ & ${ }^{\circ}$ Brix \\
\hline $\mathrm{TDF}(\mathrm{mm})$ & 0.77 * & & & & & & & & & & \\
\hline FM $(g)$ & $0.78^{*}$ & $0.96^{*}$ & & & & & & & & & \\
\hline $\mathrm{SM}(\mathrm{g})$ & $0.84 *$ & $0.83^{*}$ & $0.89 *$ & & & & & & & & \\
\hline $\operatorname{PM}(g)$ & $0.75^{*}$ & $0.99 *$ & $0.95 *$ & $0.78^{*}$ & & & & & & & \\
\hline NS (und) & $0.70^{*}$ & $0.90^{*}$ & $0.90 *$ & $0.90^{*}$ & $0.85^{*}$ & & & & & & \\
\hline TDS (mm) & $0.77 *$ & 0.54 & 0.62 & $0.76^{*}$ & 0.53 & 0.54 & & & & & \\
\hline LDS (mm) & $0.73^{*}$ & 0.38 & 0.45 & 0.55 & 0.37 & 0.24 & $0.84^{*}$ & & & & \\
\hline $\mathrm{T}(\mathrm{mm})$ & $0.71^{*}$ & 0.28 & 0.32 & 0.31 & 0.30 & 0.16 & 0.38 & 0.54 & & & \\
\hline PY (\%) & -0.45 & -0.14 & -0.26 & -0.55 & -0.04 & -0.39 & -0.54 & -0.33 & -0.27 & & \\
\hline BRIX (\%) & 0.09 & 0.25 & 0.14 & 0.00 & 0.25 & 0.26 & -0.22 & -0.45 & 0.18 & -0.15 & \\
\hline $\mathrm{pH}$ & 0.47 & 0.12 & 0.19 & 0.33 & 0.06 & 0.32 & 0.37 & 0.26 & 0.60 & -0.59 & 0.13 \\
\hline
\end{tabular}

*Significant at $5 \%$ probability by t-test.

$\mathrm{LDF}=$ longitudinal diameter of the fruit, $\mathrm{TDF}=$ transverse diameter of the fruit, $\mathrm{FM}=$ mass of the fruit, $\mathrm{SM}=$ mass of the seed, $\mathrm{PM}=$ mass of the pulp, $\mathrm{NS}=$ number of seeds, TDS $=$ transverse diameter of the seed, LDS = longitudinal diameter of the seed, $\mathrm{T}=$ thickness of the seed, $\mathrm{PY}=$ pulp yield, ${ }^{\circ} \mathrm{BRIX}=$ soluble solids of the pulp, $\mathrm{pH}=$ potential of hydrogen of the pulp.

Table 4. Correlation between variables of fruits, seeds, and chemical characteristics of the pulp of the Canaã population. Values were obtained from fruits collected in October 2013 from Porto Nacional, State of Tocantins.

\begin{tabular}{|c|c|c|c|c|c|c|c|c|c|c|c|}
\hline Canaã & $\begin{array}{l}\text { LDF } \\
(\mathrm{mm})\end{array}$ & $\begin{array}{l}\text { TDF } \\
(\mathrm{mm})\end{array}$ & $\begin{array}{c}\text { FM } \\
\text { (g) }\end{array}$ & $\begin{array}{l}\text { SM } \\
\text { (g) }\end{array}$ & $\begin{array}{l}\text { PM } \\
(\mathrm{g}) \\
\end{array}$ & $\begin{array}{c}\text { NS } \\
\text { (und) }\end{array}$ & $\begin{array}{c}\text { TDS } \\
(\mathbf{m m})\end{array}$ & $\begin{array}{l}\text { LDS } \\
(\mathrm{mm}) \\
\end{array}$ & $\begin{array}{c}\mathbf{T} \\
(\mathbf{m m})\end{array}$ & $\begin{array}{l}\text { PY } \\
(\%) \\
\end{array}$ & ${ }^{\circ}$ Brix \\
\hline TDF (mm) & $0.70^{*}$ & & & & & & & & & & \\
\hline FM (g) & $0.85^{*}$ & $0.88^{*}$ & & & & & & & & & \\
\hline SM (g) & 0.31 & 0.42 & 0.31 & & & & & & & & \\
\hline $\mathrm{PM}(\mathrm{g})$ & $0.77 *$ & $0.75^{*}$ & $0.92 *$ & 0.09 & & & & & & & \\
\hline NS (und) & 0.36 & 0.48 & 0.39 & $0.96^{*}$ & 0.15 & & & & & & \\
\hline TDS (mm) & 0.05 & 0.08 & 0.14 & 0.02 & 0.02 & -0.1 & & & & & \\
\hline LDS (mm) & 0.16 & 0.02 & 0.13 & 0.08 & 0.03 & -0.02 & $0.77^{*}$ & & & & \\
\hline $\mathrm{T}(\mathrm{mm})$ & 0.03 & -0.12 & -0.07 & 0.14 & -0.15 & 0.25 & -0.32 & 0.08 & & & \\
\hline PY (\%) & 0.1 & 0.02 & 0.22 & $-0.83^{*}$ & 0.45 & $-0.76^{*}$ & 0.02 & -0.01 & -0.1 & & \\
\hline BRIX (\%) & -0.01 & 0.08 & 0.25 & 0.04 & 0.20 & 0.17 & -0.24 & -0.2 & -0.14 & 0.10 & \\
\hline $\mathrm{pH}$ & 0.01 & 0.60 & 0.28 & 0.48 & 0.04 & 0.53 & 0.18 & 0.02 & 0.16 & -0.36 & -0.12 \\
\hline
\end{tabular}

*Significant at $5 \%$ probability by $\mathrm{t}$-test.

$\mathrm{LDF}=$ longitudinal diameter of the fruit, $\mathrm{TDF}=$ transverse diameter of the fruit, $\mathrm{FM}=$ mass of the fruit, $\mathrm{SM}=$ mass of the seed, $\mathrm{PM}=$ mass of the pulp, NS = number of seeds, TDS $=$ transverse diameter of the seed, LDS = longitudinal diameter of the seed, $\mathrm{T}=$ thickness of the seed, $\mathrm{PY}=$ pulp yield, ${ }^{\circ} \mathrm{BRIX}=$ soluble solids of the pulp, $\mathrm{pH}=$ potential of hydrogen of the pulp. 
Among the three populations studied in this investigation, the Providência population showed an intermediate number of significant correlations between the variables; there was a perfect correlation between the transverse diameter of the fruit and fruit mass (FM) (Table 5). The mass of the fruit showed a significant correlation with the dimensional variables of the fruit as well as with the mass and number of seeds. Significant correlations between seed mass (SM) and pulp mass (PM) and also between pulp mass (PM) and number of seeds (NS) were observed similar to the correlations observed for the São Judas Tadeu population.

Table 5. Correlation between variables of fruits, seeds, and chemical characteristics of the pulp of the Providência population. Values were obtained from fruits collected in October 2013 from Porto Nacional, State of Tocantins.

\begin{tabular}{|c|c|c|c|c|c|c|c|c|c|c|c|}
\hline Providência & $\begin{array}{l}\text { LDF } \\
(\mathrm{mm}) \\
\end{array}$ & $\begin{array}{l}\text { TDF } \\
(\mathbf{m m}) \\
\end{array}$ & $\begin{array}{r}\text { FM } \\
(\mathrm{g}) \\
\end{array}$ & $\begin{array}{l}\text { SM } \\
(\mathrm{g}) \\
\end{array}$ & $\begin{array}{l}\text { PM } \\
\text { (g) } \\
\end{array}$ & $\begin{array}{c}\text { NS } \\
\text { (und) } \\
\end{array}$ & $\begin{array}{r}\text { TDS } \\
(\mathrm{mm}) \\
\end{array}$ & $\begin{array}{l}\text { LDS } \\
(\mathrm{mm}) \\
\end{array}$ & $\begin{array}{c}\mathrm{T} \\
(\mathrm{mm}) \\
\end{array}$ & $\begin{array}{l}\text { PY } \\
(\%) \\
\end{array}$ & ${ }^{\circ}$ Brix \\
\hline $\mathrm{TDF}(\mathrm{mm})$ & $0.70^{*}$ & & & & & & & & & & \\
\hline $\mathrm{FM}(\mathrm{g})$ & $0.70^{*}$ & $1.00 *$ & & & & & & & & & \\
\hline $\mathrm{SM}(\mathrm{g})$ & $0.65^{*}$ & $0.94 *$ & $0.94^{*}$ & & & & & & & & \\
\hline $\operatorname{PM}(g)$ & 0.62 & $0.96^{*}$ & $0.96^{*}$ & $0.87^{*}$ & & & & & & & \\
\hline NS (und) & 0.60 & $0.81^{*}$ & $0.81 *$ & $0.88^{*}$ & $0.72 *$ & & & & & & \\
\hline TDS (mm) & 0.21 & 0.24 & 0.24 & 0.21 & 0.35 & -0.1 & & & & & \\
\hline LDS (mm) & -0.16 & 0.41 & 0.41 & 0.44 & 0.41 & 0.12 & 0.31 & & & & \\
\hline $\mathrm{T}(\mathrm{mm})$ & 0.35 & 0.07 & 0.07 & 0.07 & 0.19 & 0.04 & 0.36 & -0.38 & & & \\
\hline PY (\%) & 0.05 & -0.15 & -0.15 & -0.41 & 0.04 & -0.5 & 0.44 & -0.18 & 0.28 & & \\
\hline BRIX (\%) & -0.38 & -0.25 & -0.25 & -0.21 & -0.15 & -0.07 & -0.26 & 0.03 & 0.30 & -0.01 & \\
\hline $\mathrm{pH}$ & 0.46 & 0.11 & 0.11 & 0.28 & -0.07 & 0.36 & -0.05 & -0.26 & -0.17 & -0.41 & -0.4 \\
\hline
\end{tabular}

*Significant at $5 \%$ probability by t-test.

$\mathrm{LDF}=$ longitudinal diameter of the fruit, $\mathrm{TDF}=$ transverse diameter of the fruit, $\mathrm{FM}=$ mass of the fruit, $\mathrm{SM}=$ mass of the seed, $\mathrm{PM}=$ mass of the pulp, NS = number of seeds, TDS $=$ transverse diameter of the seed, LDS = longitudinal diameter of the seed, $\mathrm{T}=$ thickness of the seed, PY $=$ pulp yield, ${ }^{\circ} \mathrm{BRIX}=$ soluble solids of the pulp, $\mathrm{pH}=$ potential of hydrogen of the pulp.

The significant morphological correlations between variables observed in the São Judas and Providência populations were similar to those observed by Capinan et al. (2007); Ganga et al. (2010); Freitas et al. (2012); Gonçalves et al. (2013); and Nascimento, Cardoso and Cocozza (2014).

The study of phenotypic variability between and within populations was also performed using principal component analysis (PCA) (Figure 2).

The first three principal components accounted for $78.93 \%$ data variability. The variables that contributed most to the delineation of the genotypes were fruit mass, seed mass, and transverse diameter of the fruit in principal component one; the pulp yield and soluble solids in the principal component two, and transverse and longitudinal diameters of the seed in the principal component three. No group of similarity was formed, but a possible trend of formation of a subgroup containing the genotypes of the Canaã population was observable; this subgroup presented lower mean values for fruit mass, and consequently, for mass and yield of pulp as well. In this subgroup, the mean $\mathrm{pH}$ was also slightly higher than the other two populations, and there was a lower mean value for soluble solids content ( ${ }^{\circ}$ Brix).

Our findings allowed us to infer that variability occurring within the populations was largely due to the variables of fruit mass, seed mass, pulp mass, and number of seeds, while variability between populations was similar with significant differences present only for transverse diameter of the seed and soluble solids content (Table 2). The populations of São Judas Tadeu and Providência showed greater variability, as can be seen in Figure 2 , where the genotypes of these populations were observed to be more dispersed as compared to the genotypes of the Canaã population.

These variations likely occur due to the genetic variability within each population that arises from their need to cross-fertilize and due to environmental factors, such as soil, climate, and plant age (GANGA et al., 2010). 


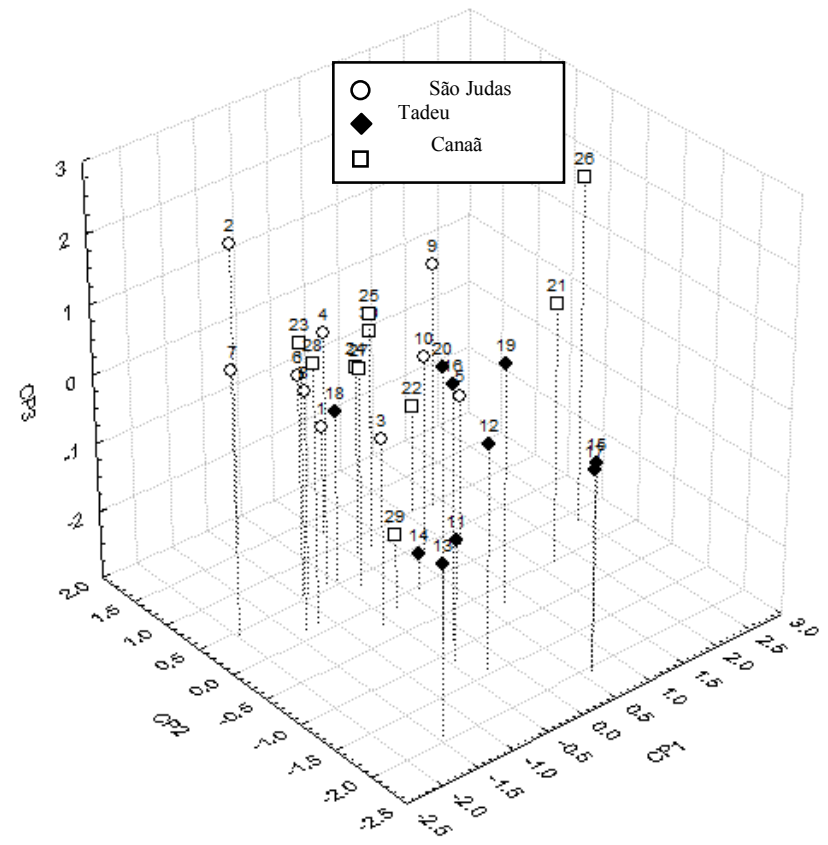

Figure 2. Dispersion of genotypes from the three natural populations of $H$. speciosa as generated from the first three principal components considering morphological variables of fruits and seeds and chemical variables of the pulp. Values were obtained from fruits collected in October 2013 from Porto Nacional, State of Tocantins.

\section{CONCLUSIONS}

The natural populations of mangabeira studied in this investigation showed similar characteristics of fruit morphology and $\mathrm{pH}$; significant differences were detected only for the transverse diameter of the seed and total soluble solid content. Although geographically distant, the populations of São Judas Tadeu and Providência were found to be more similar to each other than to the Canaã population. In general, significant correlations in each population were observed for the same variables. However, negative correlations were also observed in the Canaã population between seed mass and pulp yield as well as between the number of seeds and pulp yield. Although the differences between the populations for most of the variables studied here were not significant, the Canaã population was noted for producing more homogeneous fruit, while the Providência population was noted for producing larger fruit with greater mass. The variables that contributed most to the variability between the populations included fruit mass, seed mass, fruit transverse diameter, pulp yield, and total soluble solids content.

\section{REFERENCES}

CAPINAN, G. C. S. et al. Caracterização agronômica de plantas e frutos de mangabeiras do estado da Bahia. Magistra, Cruz das Almas, v. 19, n. 4, p. 290-298, 2007.
CARNELOSSI, M. A. G. et al. Conservação póscolheita de mangaba (Hancornia speciosa Gomes). Revista Ciência e Agrotecnologia, Lavras, v. 28, n. 5, p. 1119-1125, 2004.

CARVAlHO, J. E. U. D.; MÜlleR, C. H.; NASCIMENTO, W. M. O. D. Classificação de sementes de espécies frutíferas nativas da Amazônia de acordo com o comportamento no armazenamento. 1. ed. Belém: Embrapa Amazônia Oriental, 1999. 4 p. (Comunicado Técnico, 60).

CHITARRA, M. I. B.; CHITARRA, A. B.; CARVALHO, V. D. Algumas características dos frutos de duas cultivares de goiabeiras (Psidium guajava) em fase de maturação. In: CONGRESSO BRASILEIRO DE FRUTICULTURA, 6., 1981, Recife. Anais... Recife: Sociedade Brasileira de Fruticultura, 1981, p. 771-780.

COHEN, K. D. O.; SANO, S. M. Parâmetros físicoquímicos dos frutos de mangabeira. 1. ed. Planaltina, DF: Embrapa Cerrados, 2010. 11 p. (Boletim de Pesquisa e Desenvolvimento, 272).

DARRAULT, R. O.; SCHLINDWEIN, C. Polinização. In: SILVA JUNIOR, J. F.; LEDO, A. S. (Eds.). A cultura da mangaba. Aracaju: Embrapa Tabuleiros Costeiros, 2006. v. 1, cap. 3, p. 43-56.

DIAS, M. G. L.; MARANHÃO, T. O. Análise citogenética e palinológica quanto à viabilidade e morfologia em mangabeira (Hancornia speciosa). Biociências, Taubaté, v. 1, n. 1, p. 61-69, 1994. 
FELFILI, J. M. et al. Estudo fenológico de Stryphnodendron adstringens (Mart.) Coville no cerrado sensu stricto da Fazenda Água Limpa no Distrito Federal, Brasil. Revista Brasileira de Botânica, São Paulo, v. 22, n. 1, p. 83-90, 1999.

FERRAZ, D. K. et al. Fenologia de árvores em fragmento de mata em São Paulo, SP. Revista Brasileira de Biologia, Rio de Janeiro, v. 59, n. 2, p. 305-317, 1999.

FERREIRA, D. D. S. et al. Caracterização física e química dos frutos de mangaba (Hancornia speciosa) sob diferentes condições de armazenamento. Simpósio Latino-americano de ciência de alimentos, Campinas, v. 1, n. 4, p. 165 166. 2001.

FERREIRA, M. E.; MORETZSOHN, M. C.; BUSO, G. S. C. Fundamentos de caracterização molecular do germoplasma vegetal. In: NASS, L. L. (Ed.). Recursos Genéticos Vegetais. Brasília: Embrapa Recursos Genéticos e Biotecnologia, 2007, v. 1, cap. 11, p. 377-420.

FERRO, J. H. A. et al. Caracterização morfológica dos frutos de mangaba (Hancornia speciosa Gomes) produzidos em Alagoas. Revista Ciência Agrícola, Alagoas, v. 13, n. 1, p. 61-67, 2016.

FREITAS, M. K. C et al. Variabilidade fenotípica e caracterização morfológica de uma população natural de Hancornia speciosa Gomes. Bioscience Journal, Uberlândia, v. 28, n. 5, p. 833-841, 2012.

GANGA, R. M. D. et al. Caracterização de frutos e árvores de populações naturais de Hancornia speciosa Gomes do cerrado. Revista Brasileira de Fruticultura, Jaboticabal, v. 32, n. 1, p. 101-113, 2010 .

GONÇALVES, L. G. V. et al. Biometria de frutos e sementes de mangaba (Hancornia speciosa Gomes) em vegetação natural na região leste de Mato Grosso, Brasil. Revista de Ciências Agrárias, Recife, v. 36, n. 1, p. 31-40, 2013.

HOFFMANN, W. A. Post-establishment seedling success in the Brazilian cerrado: A comparison of savanna and forest species. Biotropica, Gainesville, v. 32 , n. 1, p. 62-69, 2000.

HOSBINO, A. A. et al. Marcador microssatélite na conservação de germoplasma vegetal. Revista Biotecnologia, Ciência e Desenvolvimento, Brasília, v. 5, n. 29, p. 146-150, 2002.

LORENZI, H. Árvores brasileiras: manual de identificação e cultivo de plantas arbóreas nativas do Brasil. 1. ed. Nova Odessa, SP: Editora
Plantarum. 1992. 368 p.

MALAVASI, U. C.; MALAVASI, M. M. Influência do tamanho e do peso da semente na germinação e no estabelecimento de espécies de diferentes estágios da sucessão vegetal. Floresta e ambiente, Rio de Janeiro, v. 8, n. 1, p. 211-215, 2001.

MATOS, V. F. Variabilidade fenotípica em uma população natural de Hancornia speciosa Gomes. 2013. 11 f. Relatório Final PIBIC (Programa Institucional de Bolsas de Iniciação Científica) Fundação Universidade Federal do Tocantins, Porto Nacional, 2013.

MONACHINO, J. A revision of Hancornia (Apocynaceae). Lilloa, Tucumán, v. 11, n. 33, p. 1948, 1945.

MOURA, N. F. et al. Seleção de marcadores RAPD para o estudo da estrutura genética de populações de Hancornia speciosa Gomes. Biosciense Journal, Uberlandia, v. 21, n. 3, p. 119-125, 2005.

NASCIMENTO, R. S. M.; CARDOSO, J. A.; COCOZZA, F. D. M. Caracterização física e físicoquímica de frutos de mangabeira (Hancornia speciosa Gomes) no oeste da Bahia. Revista Brasileira Engenharia Agrícola Ambiental, Campina Grande, v. 18, n. 8, p. 856-860, 2014.

OLIVEIRA, M. E. B. D et al. Avaliação de parâmetros de qualidade físico-químicos de polpas congeladas de acerola, cajá e caju. Food Science and Technology, Campinas, v. 19, n. 3, p. 326-332, 1999.

PEYNAUD, E. Connaissance et travail du vin. 2. ed. Paris: Dunod, 1997. 341 p.

PINTO, C. E.; OLIVEIRA, R.; SCHLINDWEIN, C. Do consecutive flower visits within a crown diminish fruit set in mass-flowering Hancornia speciosa (Apocynaceae)?. Plant Biology, Stuttgart, v. 10, n. 3, p. 408-412, 2008.

PIRANI, F. R.; SANCHEZ, M.; PEDRONI, F. Fenologia de uma comunidade arbórea em cerrado sentido restrito, Barra do Garças, MT, Brasil. Acta Botanica Brasilica, Rio de Janeiro, v. 23, n. 4, p. 1096-1109, 2009.

RIBEIRO, A. D. A. et al. Biometria de frutos, obtenção de novas progênies, clones e porta-enxertos de mangabeira. In: CONGRESSO DE ENSINO, PESQUISA E EXTENSÃO DA UEG, 2., 2015, Pirenópolis. Anais... Pirenópolis: UEG, 2015. p. 2851-2860.

ROWLEY, G. D. The pollination mechanism of 
Adenium (Apoc.). National Cactus and Succulent Journal, Claremont, v. 35, n. 1, p. 2-5, 1980.

RUFINO, M. S. M. Propriedades funcionais de frutas tropicais brasileiras não tradicionais. 2008. 237 f. Dissertação (Doutorado em fitotecnia: Área de Concentração em Agricultura Tropical) Universidade Federal Rural do Semi-Árido, Mossoró, 2008.

SÁ, A. D. J.; LÉDO, A. D. S.; LÉDO, C. A. D. S. Conservação in vitro de mangabeira da região nordeste do Brasil; In vitro conservation of mangaba tree in Northeast Brazil. Ciência Rural, Santa Maria, v. 41, n. 1, p. 57-62, 2011.

SANTOS, A. C. B. et al. Levantamento etnobotânico, químico e farmacológico de espécies de Apocynaceae Juss. ocorrentes no Brasil. Revista Brasileira Plantas Medicinais, Botucatu, v. 15, n. 3, p. 442-458, 2013.

SANTOS, D. P. Variabilidade fenotípica em uma população de Hancornia speciosa Gomes com base em variáveis morfológicas quantitativas e qualitativas. 2013. 19 f. Monografia (Bacharelado em Ciências Biológicas) - Fundação Universidade Federal do Tocantins, Porto Nacional, 2013.

SANTOS, J. T. S. et al. O. Avaliação de mangaba liofilizada através de parâmetros físico-químicos. Scientia Plena, Sergipe, v. 8, n. 3, p. 1-5, 2012.

SCHLINDWEIN, C. et al. Polinização da mangabeira (Hancornia speciosa). In: III SEMANA DOS POLINIZADORES, 1., 2012, Juazeiro. Anais... Juazeiro: UNIVASF, 2012. p. 67-75.

SILVA, A. M. L.; MARTINS, B. A.; DEUS, T. N. Avaliação do teor de ácido ascórbico em frutos do Cerrado durante o amadurecimento e congelamento. Estudos, Goiânia, v. 36, n. 11/12, p. 1159-1169, 2009.

SILVA, A. V. C. D.; SILVA, C. M. S. S. Qualidade da polpa congelada de mangaba comercializada em Aracaju, Sergipe. 1. ed. Aracaju: Embrapa Tabuleiros Costeiros, 2012. 14 p. (Boletim Pesquisa e Desenvolvimento, 70).

SILVA, L. D. P. V.; ARAÚJO, J. D. R. G.; ROCHA, A. E. Levantamento florístico e fitossociológico em áreas de ocorrência de Hancornia speciosa Gomes em Morros-MA. Cadernos de Agroecologia, Fortaleza, v. 6, n. 2, p. 1-5, 2011.

SILVA, R. S. M.; CHAVES, L. J.; NAVES, R. V. Caracterização de frutos e árvores de cagaita (Eugenia dysenterica DC.) no sudeste do Estado de
Goiás, Brasil. Revista Brasileira de Fruticultura, Jaboticabal, v. 23, n. 2, p. 330-334, 2001.

SILVA, S. A. C. et al. Caracterização morfológica e molecular de genótipos de mangaba. Revista Brasileira de Fruticultura, Jaboticabal, v. 35, n. 4, p. 1093-1100, 2013.

SILVA, S. M. C.; NASCIMENTO, J. L. D.; NAVES, R. V. Produção da Mangabeira (Hancornia speciosa Gomes) irrigada e adubada nas condições do estado de Goiás. Bioscience Journal, Uberlândia, v. 22, n. 2, p. 43-51, 2006.

SILVA JÚNIOR, J. F. A cultura da mangaba. Revista Brasileira de Fruticultura, Jaboticabal, v. 26, n. 1, p. 1, 2004.

SILVA JÚNIOR, J. F.; LÉDO, A. S. Botânica. In: SILVA JUNIOR, J. F.; LEDO, A. S. (Eds.). A cultura da mangaba. Aracaju: Embrapa Tabuleiros Costeiros, 2006. v. 1, cap. 1, p. 25-33.

SOUZA, L. B; GOMES, W. P. Mudanças microclimáticas em Porto Nacional (TO) e suas relações com o reservatório da UHE Luis Eduardo Magalhães: um estudo perceptivo com alunos do $3^{\circ}$ ano do ensino médio. Revista Geonorte, Manaus, v. 1, n. 5, p. 162-174, 2012.

SOUZA, M. D. et al. Influência das precipitações pluviométricas em atributos físico-químicos de frutos da goiabeira 'Paluma'em diferentes estádios de maturação. Revista Brasileira de Fruticultura, Jaboticabal, v. 32, n. 2, p. 637-646, 2010. 